\title{
Tratamentos pré-germinativos em sementes de duas espécies do gênero Poincianella ${ }^{1}$
}

\author{
Pre-germination treatments on the seeds of two species of the genus Poincianella
}

\author{
Elane Grazielle Borba de Sousa Ferreira ${ }^{2 *}$, Valderez Pontes Matos ${ }^{3}$, Edilma Pereira Gonçalves ${ }^{3}$, Rinaldo Luiz \\ Caraciolo Ferreira ${ }^{4}$ e Romário Bezerra e Silva ${ }^{4}$
}

\begin{abstract}
RESUMO - Objetivou-se nesse trabalho avaliar o efeito de diferentes tratamentos pré- germinativos em sementes de Poincianella bracteosa e Poincianella pyramidalis. Foram testados os seguintes tratamentos: embebição em água por 24 horas; embebição em água a $80^{\circ} \mathrm{C}$ até atingir a temperatura ambiente; escarificação com lixa; escarificação com lixa seguida da embebição em água por 24 horas; escarificação química com ácido sulfúrico concentrado por 30 segundos, 1; 5 e 10 minutos e a testemunha. A avaliação do efeito dos tratamentos foi feita pelas variáveis: germinação, primeira contagem e índice de velocidade de germinação, comprimento da raiz principal e da parte aérea e a determinação da massa seca da raiz e da parte aérea das plântulas. Concluiu-se que as sementes de P. bracteosa e P. pyramidalis não apresentam dormência tegumentar.
\end{abstract}

Palavras-chave: Catingueira. Germinação. Dormência em plantas.

\begin{abstract}
The objective of this study was to evaluate the effect of different pre-germination treatments on seeds of Poincianella bracteosa and Poincianella pyramidalis. The following treatments were tested: soaking in water for 24 hours; soaking in water at $80{ }^{\circ} \mathrm{C}$ until reaching room temperature; scarification with sandpaper; scarification followed by soaking in water for 24 hours; chemical scarification with concentrated sulphuric acid for $0.5,1,5$ and 10 minutes; and a control. Evaluation of the effect of the treatments was made, employing the following variables: germination, first count and germination speed index, main root and shoot length, and determination of the root and shoot dry mass of the seedlings. It was concluded that the seeds of P. bracteosa and P. pyramidalis do not exhibit integumentary dormancy.
\end{abstract}

Key words: Catingueira. Germination. Dormancy in plants.

\footnotetext{
*Autor para correspondência

${ }^{1}$ Recebido para publicação em 20/08/2013; aprovado em 05/03/2014

Parte da Tese de Doutorado do primeiro autor defendida na Universidade Federal Rural de Pernambuco

${ }^{2}$ Departamento de Ciência Florestal, Universidade Federal do Rural de Pernambuco, Av. Dom Manoel de Medeiros, s/n, Recife, PE, Brasil, 52.171-900,egbsf@bol.com.br

${ }^{3}$ Departamento de Agronomia, Universidade Federal do Rural de Pernambuco, Av. Dom Manoel de Medeiros, s/n, Recife, PE, Brasil, 52.171-900, vpmatos@ig.com.br, edilmapg@hotmail.com

${ }^{4}$ Departamento de Ciência Florestal, Universidade Federal do Rural de Pernambuco, Av. Dom Manoel de Medeiros, s/n, Recife, PE, Brasil, 52.171-900, rinaldo@dcfl.ufrpe.br, romariobs@gmail.com
} 


\section{INTRODUÇÃO}

A espécie Poincianella bracteosa (Benth.) L.P.Queiroz - Fabaceae-Caesalpinoidae, popularmente conhecida por catingueira, ocorre nos ambientes de caatinga, cerrados, florestas estacionais e dunas litorâneas, é potencialmente útil para recuperação de áreas degradadas (QUEIROZ, 2009). A madeira desta espécie é utilizada para fabricação de mourões, estacas, construções rústicas e carvão, suas flores são melíferas e a folhagem quando jovem serve de alimento para o gado (LIMA, 2011).

A Poincianella pyramidalis (Tul.) L.P. Queiroz ou catingueira, ocorre no Nordeste do Maranhão e Ceará até a Bahia, porém devido a disjunção geográfica, há ocorrência também desta espécie na região Norte, Estado do Amazonas (QUEIROZ, 2009). Esta espécie tem diversas utilidades como madeireiras, medicinal e forrageira, por apresentar rápido crescimento e por ter boa capacidade de rebrota, a planta é indicada para recuperação de áreas degradadas e para produção de lenha (PEREIRA et al., 2003; QUEIROZ, 2009).

A dormência é um processo que distribui a germinação no tempo para garantir que algumas sementes encontrem ambientes favoráveis para germinação e desenvolvimento pós-seminal, sendo considerado um mecanismo natural de sobrevivência de alguns vegetais, de modo que cerca de dois terços das espécies arbóreas, possuem algum tipo de dormência, cujo fenômeno é comum tanto em plantas de clima temperado, quanto nas de clima tropical e subtropical (BENEDITO et al., 2008; SENA; GARIGLIO, 2008).

Embora a dormência seja necessária para aumentar as chances de sobrevivência da espécie, ela dificulta a análise de sementes em laboratório e a produção de mudas em viveiros florestais (BRANCALION; MONDO; NOVEMBRE, 2011). Esse fenômeno ocorre quando as sementes de uma determinada espécie, mesmo estando viáveis e tendo todas as condições ambientais favoráveis, não germinam (CARVALHO; NAKAGAWA, 2012). De acordo com Davide e Silva (2008) as condições favoráveis para a germinação das sementes são presença de umidade, luz, oxigênio e temperatura adequada, embora outros fatores também podem interferir de forma direta ou indireta no processo de germinação como: tipo do substrato, profundidade de semeadura, estádio de maturação, sanidade da semente entre outros.

A dormência das sementes pode ter diversas causas, de modo que, para cada tipo e condição na qual as sementes estão inseridas haverá um ou mais métodos adequados e eficientes para sua superação (ZAIDAN; BARBEDO, 2004). As principais causas da dormência são impermeabilidade do tegumento, imaturidade fisiológica do embrião, presença de substâncias inibidoras, embrião dormente e combinação de causas, uma vez que pode haver na mesma espécie mais de uma causa de dormência (VIEIRA; FERNANDES, 1997).

Quando as sementes de uma determinada espécie apresentam dormência, é necessário a realização de tratamentos pré-germinativos caso deseje que a germinação ocorra mais rapidamente, como no caso das espécies saguaraji-vermelho (Colubrina glandulosa Perkins) que deve ser submetida à imersão em ácido sulfúrico por 30 ou 90 minutos (BRANCALION; MONDO; NOVEMBRE, 2011) e esponjeira (Vachellia farnesiana (L.) Wight \& Arn.) que deve ser escarificada mecanicamente com lixa para madeira $n^{\circ} .120$ (MORAES et al., 2012).

Assim objetivou-se neste trabalho avaliar o efeito de diferentes tratamentos pré-germinativos em sementes de Poincianella bracteosa e Poincianella pyramidalis.

\section{MATERIAL E MÉTODOS}

Os frutos de Poincianella bracteosa (Tul.) L.P. Queiroz foram coletados de árvores matrizes localizadas na Fazenda Itapemirim, município de Floresta, Pernambuco. As sementes de Poincianella pyramidalis (Tul.) L.P. Queiroz foram obtidas de frutos, provenientes de árvores matrizes, localizadas na Estação Experimental da Fazenda Saco, pertencente à Empresa Pernambucana de Pesquisa Agropecuária (IPA), no município de Serra Talhada, Pernambuco. Após a coleta, os frutos foram submetidos ao beneficiamento manual para extração das sementes.

As sementes de $P$. bracteosa e $P$. pyramidalis com grau de umidade de 10,7 e $12,1 \%$, respectivamente, foram submetidas aos seguintes tratamentos pré-germinativos:

T1 - testemunha;

T2 - embebição em água por 24 horas;

$\mathrm{T} 3$ - embebição em água a $80^{\circ} \mathrm{C}$ até atingir a temperatura ambiente;

T4 - escarificação com lixa $n^{\circ} 100$ para massa;

T5 - escarificação com lixa $n^{\circ} 100$ para massa seguida de embebição em água por 24 horas;

T6 - escarificação química com ácido sulfúrico concentrado durante 30 segundos,

T7 - escarificação química com ácido sulfúrico concentrado durante 1 minuto,

T8 - escarificação química com ácido sulfúrico concentrado durante 5 minutos.

T9- escarificação química com ácido sulfúrico concentrado durante 10 minutos 
Em todos os tratamentos, as sementes foram desinfestadas em solução de hipoclorito de sódio a $5 \%$ durante cinco minutos, e lavadas com água deionizada.

A semeadura foi feita em caixas plásticas transparentes (tipo gerbox) medindo $11 \times 11 \times 3 \mathrm{~cm}$, com quatro repetições de 25 sementes, entre o substrato areia, umedecido com solução de nistatina a $0,2 \%$, e mantidas em câmara de germinação tipo BOD (Biochemical Oxigen Demand), regulada à temperatura constante de $25^{\circ} \mathrm{C}$ e luz contínua. Na Regras para Analise de Sementes não existe instruções especificas para analise de sementes das espécies estudadas. O número de sementes germinadas foi avaliado diariamente, adotando-se como critério de germinação, o surgimento do hipocótilo e a consequente emergência dos cotilédones.

Os parâmetros avaliados foram: germinação (\%) correspondeu à porcentagem total de sementes germinadas até o $15^{\circ}$ dia após a semeadura; primeira contagem correspondeu à porcentagem de sementes germinadas no período de ocorrência das primeiras plântulas normais que aconteceunoquinto dia após a semeadura,índice velocidade de germinação (IVG) - avaliada concomitantemente com o teste de germinação, no qual foram efetuadas as contagens diárias das plântulas normais, do quinto até o décimo quinto dia após a semeadura, e o índice calculado de acordo com Maguire (1962); comprimento de raízes e parte aérea das plântulas - ao final do teste de germinação, o hipocótilo e a raiz principal das plântulas normais de cada repetição foram medidos com auxílio de uma régua graduada em centímetros, sendo os resultados expressos em centímetros por plântula; massa seca de raízes e parte aérea das plântulas - após mensurar o comprimento da parte aérea e do sistema radicular, as plântulas foram acondicionados em sacos de papel, identificados e levados à estufa, regulada a $80^{\circ} \mathrm{C}$ por 24 horas. Após este período, retirou-se o material da estufa onde o mesmo foi pesado em balança analítica, com precisão de $0,001 \mathrm{~g}$ e os resultados expressos em mg/plântula (NAKAGAWA, 1999).

Utilizou-se o delineamento inteiramente casualizado com quatro repetições de 25 sementes e a comparação das médias foi feita pelo teste de Scott-Knott em nível de 5\% de probabilidade. A análise estatística foi realizada utilizando-se o programa estatístico SISVAR (DEX/UFLA), versão 5.3/1999-2010.

\section{RESULTADOS E DISCUSSÃO}

As maiores porcentagens de germinação de sementes de P. bracteosa (Figuras 1A e 1B) foram obtidas nas sementes submetidas à embebição em água a $80{ }^{\circ} \mathrm{C}$ até atingir a temperatura ambiente; escarificação com lixa e escarificação química com ácido sulfúrico concentrado durante 30 segundos, 1; 5 e 10 minutos, não diferiram estatisticamente da testemunha. Os tratamentos embebição em água por 24 horas (T2) e escarificação com lixa, seguida de embebição em água por 24 horas (T5) proporcionaram as menores porcentagens de germinação, portanto estes tratamentos não são indicados para esta espécie.

Figura 1 - Germinação (\%) (A), primeira contagem da germinação (\%) (B) e índice de velocidade de germinação (IVG) (C) de sementes de Poincianella bracteosa (Tul.) L. P. Queiroz submetidas a diferentes tratamentos pré-germinativos
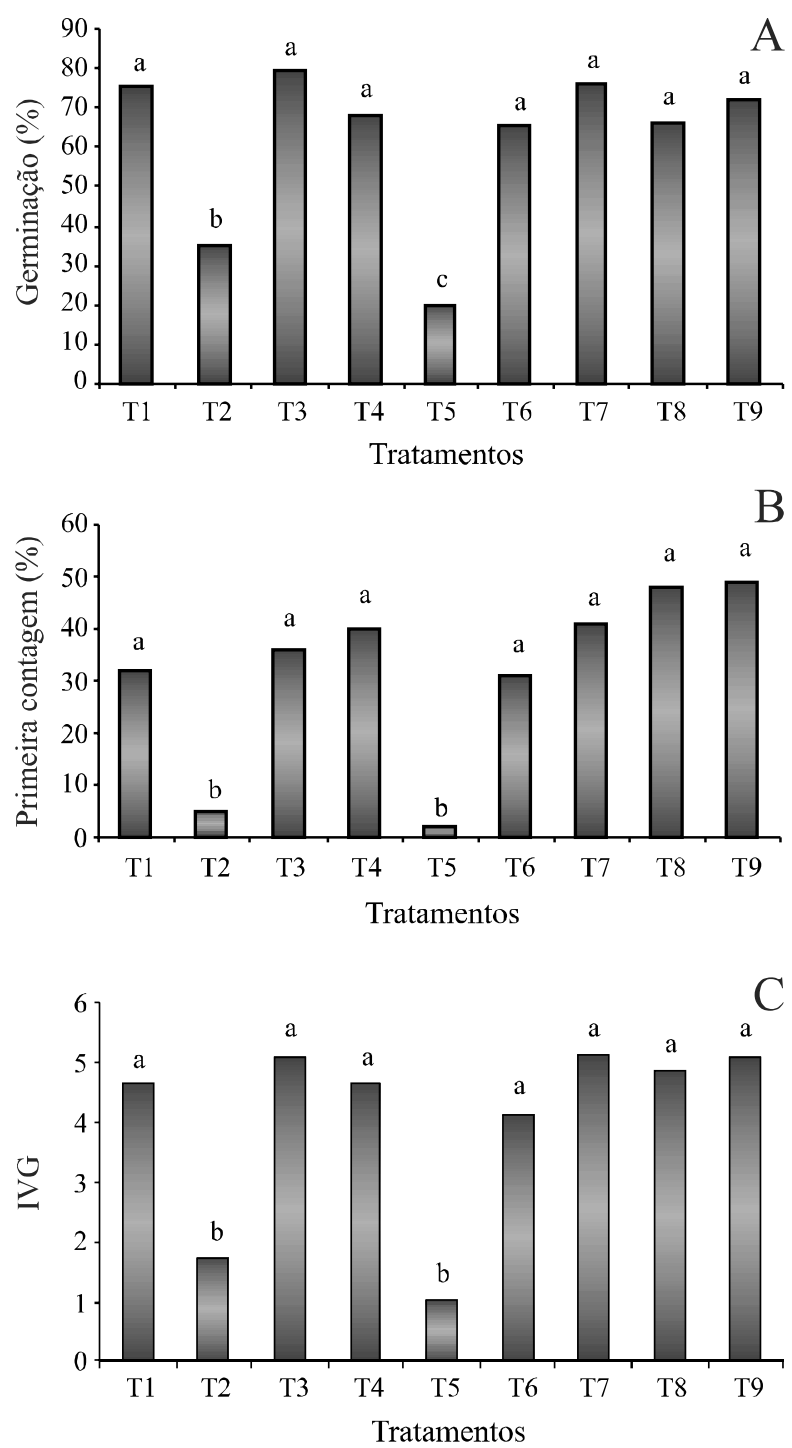

T1 - testemunha; T2 - embebição em água por 24 horas; T3 - embebição em água a $80^{\circ} \mathrm{C}$ até atingir a temperatura ambiente; $\mathrm{T} 4$ - escarificação com lixa; T5 - escarificação com lixa seguida de embebição em água por 24 horas; T6, T7, T8 e T9 - escarificação química com ácido sulfúrico concentrado por 30 segundos, 1; 5 e 10 minutos, respectivamente. Médias seguidas da mesma letra não diferem entre si pelo teste Scott-Knott a $5 \%$ de probabilidade $(\mathrm{CV}=16,97 \%$, $41,71 \%$ e $21,50 \%$, respectivamente) 
A indicação de determinado método para a superação da dormência deve permitir que a maioria das sementes dormentes expresse seu potencial fisiológico após a aplicação do mesmo, apresentando germinação rápida e uniforme (BRANCALION; MONDO; NOVEMBRE, 2011). Para as sementes de canafístula (Cassia grandis L.f.) o tratamento mais eficiente para superação da dormência foi a imersão em ácido sulfúrico por 30 minutos, que resultou em $72 \%$ de germinação, semelhante aos resultados obtidos com a espécie em estudo, onde os tratamentos das sementes com ácido sulfúrico favoreceram a germinação, porém não sendo superior a testemunha. Entretanto, não houve germinação das sementes de canafístula quando submetidas aos tratamentos com imersão em água a $80^{\circ} \mathrm{C}$ por 1; 3 e 5 minutos (MELO; RODOLFO JÚNIOR, 2006).

A imersão das sementes em água quente é um método vantajoso, de baixo custo e eficiente para superar a dormência de algumas leguminosas (BORTOLINI et al., 2011), a imersão em água a $80^{\circ} \mathrm{C}$ também foi eficiente para as sementes de $P$. bracteosa, que apresentaram $80 \%$ de germinação, mas não apresentou diferença significativa em relação as sementes que não receberam tratamento pré-germinativo (Figura 1A).

O índice de velocidade de germinação (IVG) foi maior tanto nas sementes sem tratamento como naquelas submetidas aos tratamentos pré-germinativos, com exceção apenas da embebição em água por 24 horas e da escarificação com lixa, seguida de embebição em água por 24 horas, possivelmente o tempo de embebição utilizado nestes tratamentos foi excessivo, afetando a viabilidade do embrião (Figura 1C).

Em relação ao comprimento da raiz principal das plântulas de P. bracteosa (Figura 2) os maiores comprimentos foram obtidos quando as sementes receberam os tratamentos embebição em água por 24 horas (T2), escarificação química com ácido sulfúrico concentrado durante 30 segundos, 1 e 5 minutos (T6, T7 e T8) e nas sementes sem tratamento (T1). Na espécie quixabeira (Sideroxylon obtusifolium (Roem. \& Schult.) T. D. Penn.), a escarificação das sementes com lixa $\mathrm{n}^{\mathrm{o}} 50$ sem embebição, proporcionaram maior comprimento da raiz primária de suas plântulas (REBOUÇAS et al., 2012).

O comprimento da parte aérea das plântulas e massa seca da parte aérea das plântulas (Figuras 2 e 3) apresentaram resultados inferiores, quando as sementes receberam o tratamento escarificação com lixa seguida de embebição em água por 24 horas (T5). As sementes submetidas aos demais tratamentos, favoreceram o crescimento e o acúmulo de massa seca na parte aérea das plântulas.

As plântulas de $P$. bracteosa apresentaram maior acúmulo de massa seca do sistema radicular (Figura 3) quando foram originadas de sementes sem tratamentos (testemunha), assim como naquelas que receberam os demais tratamentos, com exceção das que receberam
Figura 2 - Comprimento $(\mathrm{cm})$ da raiz primária e parte aérea de plântulas de Poincianella bracteosa (Tul.) L. P. Queiroz, oriundas de sementes submetidas a diferentes tratamentos pré-germinativos

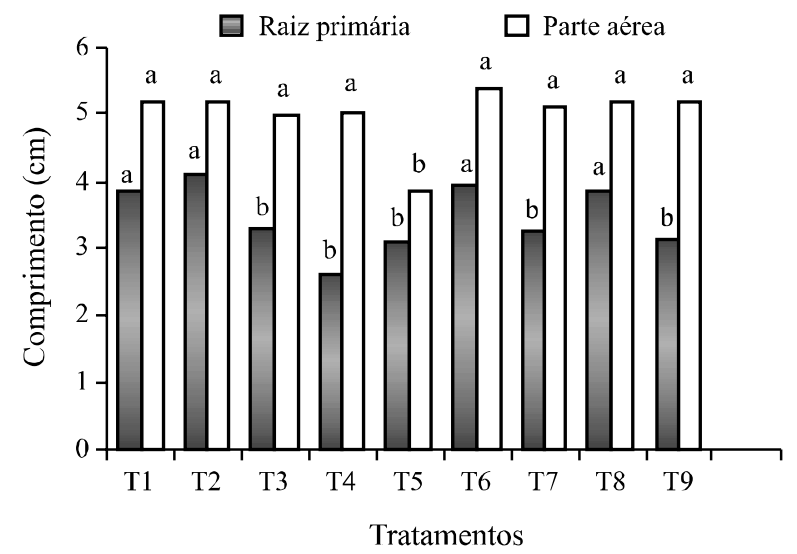

T1 - testemunha; T2 - embebição em água por 24 horas; T3 embebição em água a $80{ }^{\circ} \mathrm{C}$ até atingir a temperatura ambiente; T4 - escarificação com lixa; T5 - escarificação com lixa seguida de embebição em água por 24 horas; T6, T7, T8 e T9 - escarificação química com ácido sulfúrico concentrado por 30 segundos, 1; 5 e 10 minutos, respectivamente. Médias seguidas da mesma letra não diferem entre si pelo teste Scott-Knott a $5 \%$ de probabilidade $(\mathrm{CV}=$ $21,28 \%$ e $10,04 \%$, respectivamente)

Figura 3 - Massa seca (mg) do sistema radicular e parte aérea de plântulas de Poincianella bracteosa (Tul.) L. P. Queiroz, oriundas de sementes submetidas a diferentes tratamentos pré-germinativos

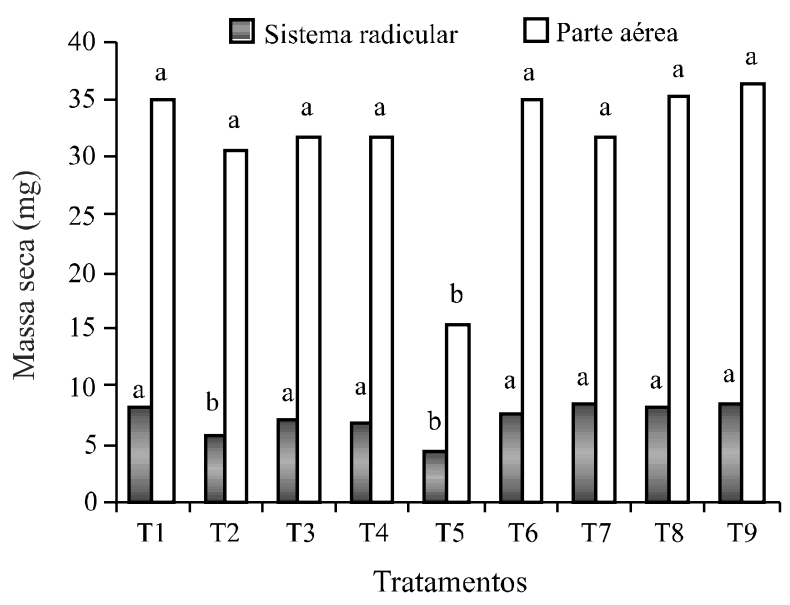

T1 - testemunha; T2 - embebição em água por 24 horas; T3 - embebição em água a $80{ }^{\circ} \mathrm{C}$ até atingir a temperatura ambiente; T4 - escarificação com lixa; T5 - escarificação com lixa seguida de embebição em água por 24 horas; T6, T7, T8 e T9 - escarificação química com ácido sulfúrico concentrado por 30 segundos, 1; 5 e 10 minutos, respectivamente. Médias seguidas da mesma letra não diferem entre si pelo teste Scott-Knott a 5\% de probabilidade $(\mathrm{CV}=27,50 \%$ e $19,16 \%$, respectivamente $)$

os tratamentos embebição em água por 24 horas e escarificação com lixa, seguida de embebição em água 
por 24 horas, que originaram plântulas menos vigorosas. Possivelmente, o tempo de embebição das sementes em água foi excessivo e provocou danos ao embrião, reduzindo o potencial germinativo e vigor.

As sementes de várias espécies têm sua germinação bloqueada pela barreira que os tegumentos impõem à embebição de água (MELO; RODOLFO JÚNIOR, 2006). Entretanto, observou-se que o tegumento das sementes de $P$. bracteosa não constitui um impedimento à entrada de água.

Os tratamentos de escarificação química com ácido sulfúrico, por períodos de $1(69 \%)$ e 5 minutos $(69 \%)$ (T7 e T8, respectivamente), assim como a testemunha (T1) foram eficientes para promover maior germinação das sementes de $P$. pyramidalis (65\%). Entretanto, o tratamento feito por embebição em água a $80{ }^{\circ} \mathrm{C}$ até atingir a temperatura ambiente (T3) não foi favorável à germinação das sementes, pois estas expressaram apenas $10 \%$ de germinação (Figura 4A).

As sementes de Erythrina variegata L. dispensaram a adoção de tratamentos pré-germinativos (MATHEUS; LOPES, 2007). Em estudo realizado por Lima et al. (2011), as sementes de Caesalpinia pyramidalis Tul., que não receberam tratamentos para superação da dormência e quando mantidas no substrato areia e temperatura de $25{ }^{\circ} \mathrm{C}$ expressaram $65 \%$ de germinação, o que corrobora com os resultados obtidos neste estudo, cuja germinação das sementes de $P$. pyramidalis sem tratamento foi de $65 \%$.

A maior porcentagem de germinação na primeira contagem (Figura 4B) foi obtida com as sementes que não foram submetidas a tratamentos pré-germinativos (16\%) (T1) e, ao serem submetidas à embebição em água a $80^{\circ} \mathrm{C}$ até atingir a temperatura ambiente (T3) (0\%) e escarificação com lixa, seguida de embebição em água por 24 horas $(0 \%)$ (T5) não germinaram no período da primeira contagem, resultado diferente do obtido por Pacheco et al. (2011), que observaram que a escarificação mecânica das sementes de fava d'anta (Dimorphandra mollis Benth.) proporcionou maior porcentagem de sementes germinadas na primeira contagem.

A maior rapidez na germinação das sementes de $P$. pyramidalis foi observada quando as sementes foram semeadas sem nenhum tratamento para superação da dormência (testemunha - T1), bem como com escarificação química em ácido sulfúrico por 1 e 5 minutos (T7 e T8, respectivamente), enquanto a germinação ocorreu de forma muito lenta quando as sementes foram submetidas a embebição em água a $80^{\circ} \mathrm{C}$ até atingir a temperatura ambiente (T3) (Figura 4C). Possivelmente, a temperatura de $80{ }^{\circ} \mathrm{C}$ causou danos ao embrião das sementes desta espécie, prejudicando a germinação e a velocidade de germinação.
Figura 4 - Germinação (\%) (A), primeira contagem da germinação (\%) (B) e índice de velocidade de germinação (C) de sementes de Poincianella pyramidalis (Tul.) L. P. Queiroz submetidas a diferentes tratamentos pré-germinativos
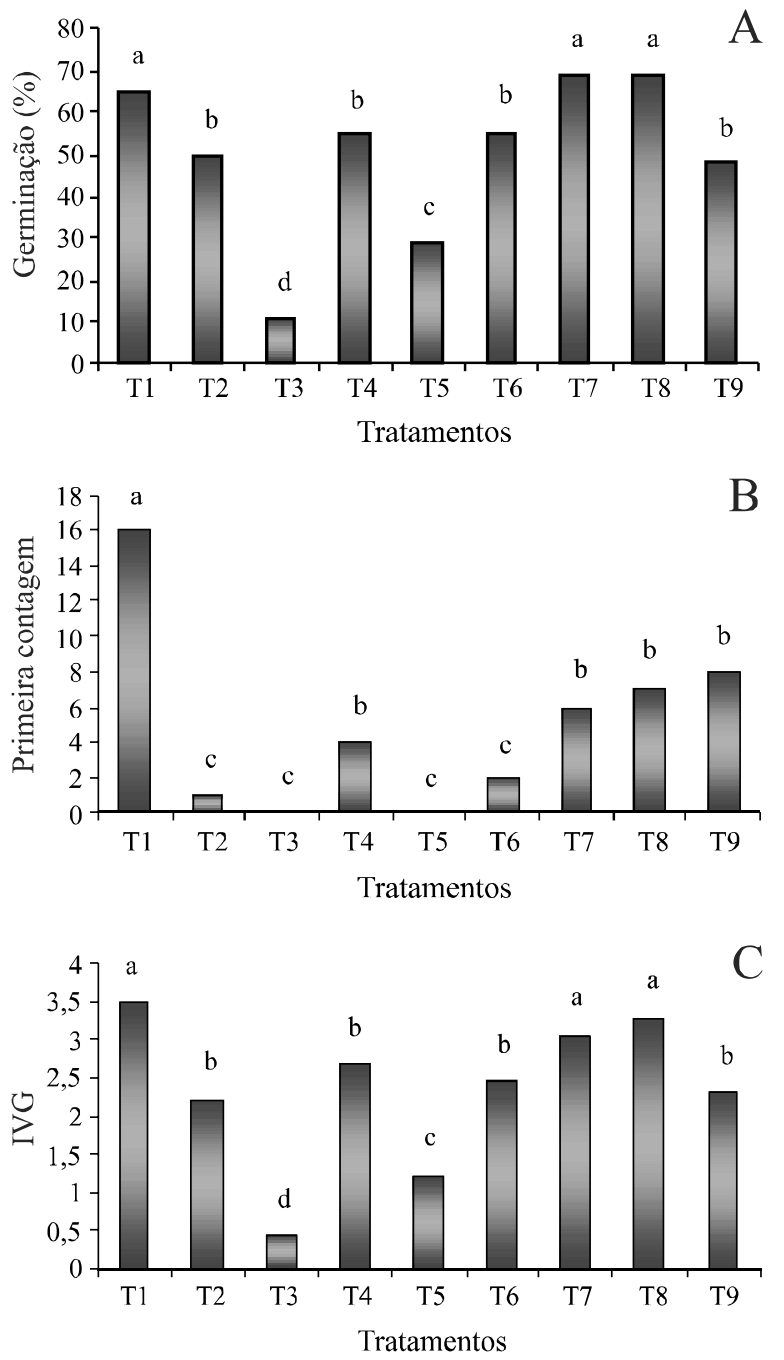

T1 - testemunha; T2 - embebição em água por 24 horas; T3 - embebição em água a $80^{\circ} \mathrm{C}$ até atingir a temperatura ambiente; T4 - escarificação com lixa; T5 - escarificação com lixa seguida de embebição em água por 24 horas; T6, T7, T8 e T9 - escarificação química com ácido sulfúrico concentrado por 30 segundos, 1 ; 5 e 10 minutos, respectivamente. Médias seguidas da mesma letra não diferem entre si pelo teste Scott-Knott a $5 \%$ de probabilidade $(\mathrm{CV}=13,05 \%, 58,78 \%$ e $19,00 \%$, respectivamente)

Resultados semelhantes ao da espécie $P$. pyramidalis foram obtidos com sementes de sapoti (Achras sapota L.), cuja porcentagem e velocidade de emergência sem nenhum tratamento foi alta (68\% e 0,42, respectivamente) (MATOS et al., 2003). No entanto, diferentemente, para a espécie Stylosanthes capitata Sw., o tratamento recomendado para superação da dormência foi a exposição das sementes à temperatura de $70{ }^{\circ} \mathrm{C}$ por 15 horas, por ter proporcionado melhor 
percentual de germinação (53\%) e maior índice de velocidade de germinação (IVG) (16,5) (ALENCAR et al., 2009).

Os tratamentos pré-germinativos podem ser aplicados às sementes florestais, com objetivo de superar algum bloqueio que está impedindo que o processo germinativo ocorra (OLIVEIRA, 2007). Entretanto, a velocidade de germinação das sementes de $P$. pyramidalis que não receberam tratamento foi rápida sugerindo que não há necessidade de utilizar os tratamentos para superação da dormência.

As sementes que receberam nenhum tratamento (testemunha - T1) originaram plântulas bastante vigorosas, quanto ao comprimento da raiz primária e parte aérea (Figura 5) observando-se 9,0 cm e 5,5 $\mathrm{cm}$ como maiores médias de comprimento da raiz primária e parte aérea das plântulas, respectivamente. O comprimento da parte aérea das plântulas originadas por sementes tratadas com embebição em água por 24 horas (T2); escarificação com lixa (T4); escarificação química com ácido sulfúrico concentrado durante 30 segundos, 1; 5 e 10 minutos (T6, T7, T8 e T9, respectivamente) os resultados também foram satisfatórios, corresponderam a 4,0; 5,0; 5,0; 5,0 4,5 e $4,0 \mathrm{~cm}$, respectivamente, mas não houve diferença significativa da testemunha.

Resultados similares de comprimento da raiz das plântulas de jucá (Caesalpinia ferrea Mart. ex Tul. var. ferrea) foram obtidos no tratamento com sementes não escarificadas (testemunha) (AVELINO et al., 2012). Ao contrário, Bortolini et al. (2011) observaram que, para superação da dormência de sementes de sucará (Gleditschia amorphoides Taub.), os melhores métodos foram a escarificação mecânica com lixa de papel $n^{\circ}$. 120, seguida de embebição, e escarificação química com ácido sulfúrico por uma ou duas horas.

O maior acúmulo de massa seca do sistema radicular das plântulas de $P$. pyramidalis foi obtido quando as sementes não receberam tratamentos pré-germinativos (T1), enquanto a massa seca da parte aérea foi maior quando as plântulas foram oriundas das sementes submetidas aos tratamentos pré-germinativos testados, inclusive a testemunha, com exceção das sementes que receberam os tratamentos de embebição em água a $80{ }^{\circ} \mathrm{C}$ até atingir a temperatura ambiente (T3), e escarificação com lixa n $^{\circ} 100$ para massa seguida de embebição em água por 24 horas (T5) (Figura 6). Os tratamentos que proporcionaram maior acúmulo de massa seca do sistema radicular e da parte aérea das plântulas foram os mesmos que ocasionaram maior comprimento da raiz primária e comprimento da parte aérea das plântulas, respectivamente.

Avelino et al. (2012) observaram que a escarificação mecânica e química mais 24 horas de embebição das
Figura 5 - Comprimento $(\mathrm{cm})$ da raiz primária e parte aérea de plântulas de Poincianella pyramidalis (Tul.) L. P. Queiroz, oriundas de sementes de submetidas a diferentes tratamentos prégerminativos

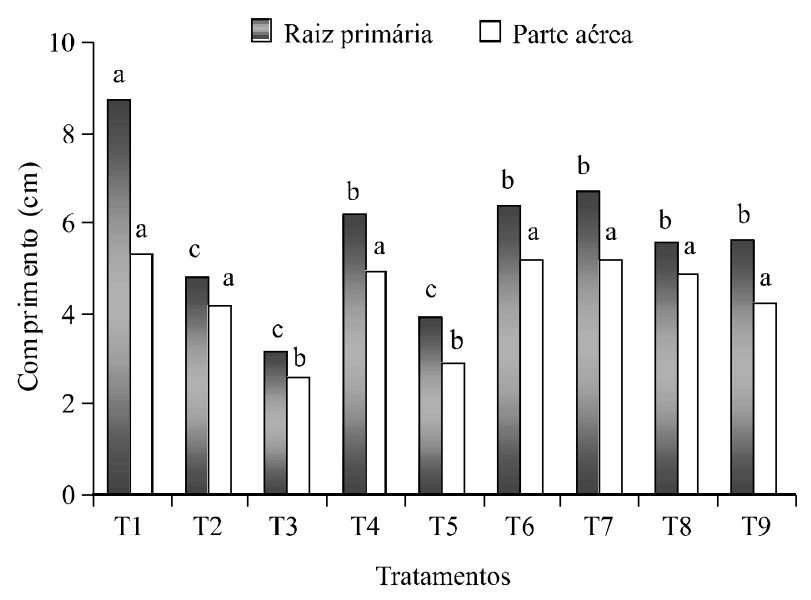

T1 - testemunha; T2 - embebição em água por 24 horas; T3 - embebição em água a $80^{\circ} \mathrm{C}$ até atingir a temperatura ambiente; T4 - escarificação com lixa; T5 - escarificação com lixa seguida de embebição em água por 24 horas; T6, T7, T8 e T9 - escarificação química com ácido sulfúrico concentrado por 30 segundos, 1; 5 e 10 minutos, respectivamente. Médias seguidas da mesma letra não diferem entre si pelo teste Scott-Knott a 5\% de probabilidade (CV $=17,61 \%$ e $15,61 \%$, respectivamente)

Figura 6 - Massa seca $(\mathrm{mg})$ do sistema radicular e parte aérea de plântulas de Poincianella pyramidalis (Tul.) L. P. Queiroz, oriundas de sementes de submetidas a diferentes tratamentos pré-germinativos

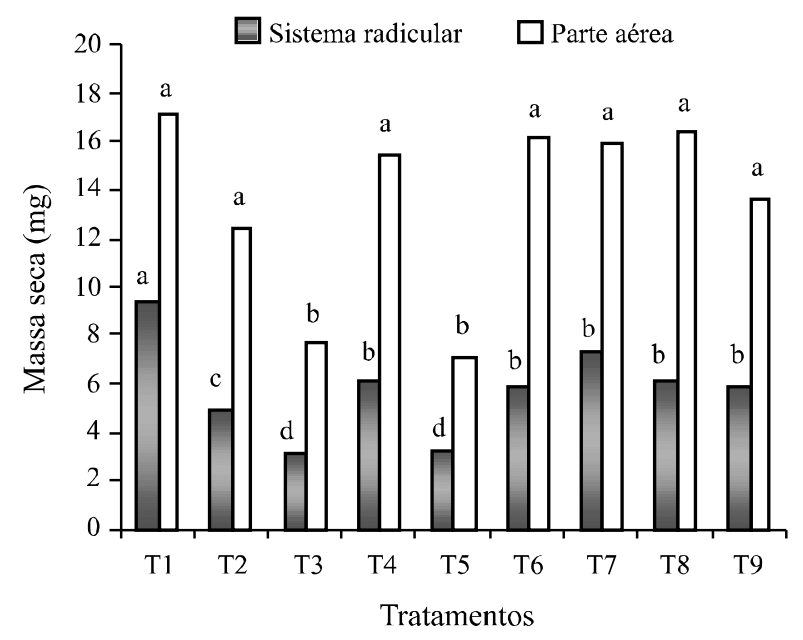

T1 - testemunha; T2 - embebição em água por 24 horas; T3 embebição em água a $80{ }^{\circ} \mathrm{C}$ até atingir a temperatura ambiente; T4 - escarificação com lixa; T5 - escarificação com lixa seguida de embebição em água por 24 horas; T6, T7, T8 e T9 - escarificação química com ácido sulfúrico concentrado por 30 segundos, 1; 5 e 10 minutos, respectivamente. Médias seguidas da mesma letra não diferem entre si pelo teste Scott-Knott a $5 \%$ de probabilidade. $(\mathrm{CV}=$ $19,29 \%$ e $21,93 \%$, respectivamente) 
sementes, também destacaram-se como os tratamentos mais promissores ao acúmulo de massa seca das plântulas de jucá (Caesalpinia ferrea Mart. ex Tul. var. ferrea). Segundo o mesmo autor uma das dificuldades na realização do teste de germinação e produção de mudas de espécies florestais da família Fabaceae decorre do controle da entrada de água, desempenhado pelo tegumento, que é recoberto ou constituído, de substâncias que promovem uma barreira, o que constitui um empecilho à germinação. Portanto, a partir dos parâmetros avaliados observa-se que o tegumento das sementes de $P$. bracteosa e $P$. pyramidalis não se constitui em impedimento ao processo germinativo.

\section{CONCLUSÃO}

As sementes de $P$. bracteosa e $P$. pyramidalis não apresentam dormência tegumentar.

\section{REFERÊNCIAS}

ALENCAR, K. M. C. et al. Tratamento térmico para superação da dormência em sementes de Stylosanthes SW. (Fabaceae Papilionoideae). Revista Brasileira de Sementes, v. 31, n. 2, p. 164-170, 2009.

AVELINO, J. I. et al. Métodos de quebra de dormência em sementes de jucá (Caesalpinia ferrea Mart. ex Tul. var. ferrea). Revista Verde, v. 7, n. 1, p. 102 -106, 2012.

BENEDITO, C. P. et al. Superação da dormência de sementes de catanduva (Piptadenia moniliformis Benth.). Revista Ciência Agronômica, v. 39, n. 1, p. 90-93, 2008.

BORTOLINI, M. F. et al. Superação de dormência em sementes de Gleditschia amorphoides Taub. Ciência Rural, v. 41, n. 5, p. 823-827 2011.

BRANCALION, P. H. S.; MONDO, V. H. V.; NOVEMBRE, A. D. L. C. Escarificação química para a superação da dormência de sementes de saguaraji-vermelho (Colubrina glandulosa Perk. - Rhamnaceae). Revista Árvore, v. 35, n. 1, p.119-124, 2011.

CARVAlHO, N. M.; NAGAGAWA, J. Sementes: ciência, tecnologia e produção. Jaboticabal: FUNEP, 2012. 590 p.

DAVIDE, A. C.; SILVA, E. A. A. Sementes florestais. In: DAVIDE, A. C.; SILVA, E. A. A. Produção de sementes e mudas de espécies florestais. Lavras: Ed. UFLA, 2008. p. 11-82.

LIMA, B. G. Caatinga: espécies lenhosas e herbáceas. Mossoró: EDUFERSA, 2011. 316 p.
LIMA, C. R. et al. Temperaturas e substratos na germinação de sementes de Caesalpinia pyramidalis Tul. Revista Brasileira de Sementes, v. 33, n. 2, p. 216 - 222, 2011.

MAGUIRE, J. D. Speed of germination-aid in selection and evaluation for seedlings emergence and vigor. Crop Science, v. 2, n. 1, p. 176-177, 1962.

MATHEUS, M. T.; LOPES, J. C. Morfologia de frutos, sementes e plântulas e germinação de sementes de Erythrina variegata $\mathrm{L}$. Revista Brasileira de Sementes, v. 29, n. 3, p. 8-17, 2007.

MATOS, V. P. et al. Sementes de sapoti (Achras sapota L.) dormência e emergência. Pesquisa Agropecuária Tropical, v. 33, n. 2, p.79-82, 2003.

MELO, R. R.; RODOLFO JÚNIOR, F. Superação de dormência em sementes e desenvolvimento inicial de canafístula (Cassia grandis L. F.). Revista Científica Eletrônica de Engenharia Florestal, v. 4, n. 7, 2006.

MORAES, F. G. D. et al. Tratamentos pré-germinativos em sementes de Vachellia farnesiana (L.) Wight \& Arn. - LeguminosaeMimosoidae. Scientia Plena, v. 8, n. 4, p. 1-5, 2012.

NAKAGAWA, J. Teste de vigor baseados no desempenho das plântulas. In: KRZYZANOWSKI, F. C.; VIEIRA, R. D.; FRANÇA NETO, J. B. (Ed). Vigor de sementes: conceitos e testes. Londrina: ABRATES, 1999, p. 2.1- 2.21.

OLIVEIRA, O. S. Tecnologia de sementes florestais. Curitiba: Imprensa Universitária, 2007. 185 p.

PACHECO, M. V. et al. Dormência de sementes e produção de mudas de Dimorphandra mollis Benth. Ciência Florestal, v. 21, n. 4, p. 689-697, 2011.

PEREIRA, S. C. et al. Plantas úteis do nordeste do Brasil. Recife: CNIP: APNE, 2003. 140 p.

QUEIROZ, L. P. Leguminosas da caatinga. Feira de Santana: Universidade Estadual de Feira de Santana, 2009. 467 p.

REBOUÇAS, A. C. M. N. et al. Métodos para superação da dormência de sementes de quixabeira (Sideroxylon obtusifolium (Roem. \& Schult.) T.D.Penn.). Ciência Florestal, v. 22, n. 1, p. 183-192, 2012.

SENA, C. M.; GARIGLIO, M. A. Sementes Florestais: colheita, beneficiamento e armazenamento. Natal: MMA, 2008. 28 p.

VIEIRA, I. G.; FERNANDES, G. D. Métodos de quebra de dormência de sementes. São Paulo, 1997. Disponível em: < http://www.ipef.br/tecsementes/dormencia.asp>. Acesso em: 30 nov. 2012.

ZAIDAN, L. B. P.; BARBEDO, C. J. Quebra de dormência em sementes. In: FERREIRA, F. G.; BORGHETTI, F. Germinação: do básico ao aplicado. Porto Alegre: Artmed, 2004. Cap. 8. p. 135-146. 